\title{
Antibody Production to Milk Proteins in the Jejunal Mucosa of Children with Cow's Milk Protein Intolerance
}

\author{
J. R. PEARSON, ${ }^{(43)}$ D. KINGSTON, AND M. SHINER \\ Intestinal Studies Group, Clinical Research Centre, Harrow HA1 3UJ, Middlesex, England
}

\begin{abstract}
Summary
A direct immunofluorescent technique with fluorescein-labeled antigens was used to examine the jejunal mucosa for specific antibody production in 23 children aged 2-25 months referred for diagnostic biopsy. Plasma cells containing antibodies to $\beta$-lactoglobulin $(\beta L G)$ or bovine serum albumin (BSA) were present in 11 of 16 biopsies from patients with cow's milk protein intolerance (CMPI) but only one of eight controls, all on a diet containing cow's milk. Antibody-containing cells $(\mathrm{ACC})$ constituted approximately $0.5-5 \%$ of the total $(\mathrm{IgA}+\mathrm{IgM})$ plasma cell population. Their presence did not correlate with either histologic abnormality or IgA plasma cell count. Double immunofluorescence with rhodamine-labeled antigens and fluorescein-labeled class-specific anti-human immunoglobulin sera showed the ACC to be approximately $70 \%$ IgA cells and $30 \%$ IgE cells.
\end{abstract}

\section{Abbreviations}

ACC, antibody-containing cells

$\beta L G$, beta-lactoglobulin

BSA, bovine serum albumin

CM, cow's milk

CMPI, cow's milk protein intolerance

$\mathrm{DAB}$, diaminobenzidine

FITC, fluorescein isothiocyanate

OD, optical density

PBS, phosphate buffered saline

TRITC, tetramethylrhodamine isothiocyanate

In children with CMPI there may be gastrointestinal symptoms only, or these may be combined with other allergic manifestations such as eczema or asthma. In many CMPI children diagnostic tests for allergy-skin prick tests or RAST-are negative and the serum $\operatorname{IgE}$ is not raised $(7,11,20)$. This is especially so in those children with only gastrointestinal symptoms. But challenge with cow's milk often produces profound changes in the small intestinal mucosa, including villous atrophy of varying degree $(9,10,12,34)$ and increased numbers of eosinophils (4I) intra-epithelial lymphocytes (40) and plasma cells $(10,21,33,34)$. It has not been established whether the increase in plasma cells is just part of a generalized, non-specific response of the immune system to antigenic stimulation $(23,37)$ or whether it represents a specific response to milk-protein antigens at the point of entry.

In order to study the mucosal immune response to bovine milk proteins we have developed a simple direct immunofluorescent technique for the presence of plasma cells containing specific antibody to two bovine milk proteins, $\beta \mathrm{LG}$ and BSA. Brief, preliminary reports of this work have been published $(16,27)$.

\section{MATERIALS AND METHODS}

Patients. Twenty-three children, aged 2-25 months, had been routinely referred to us for diagnostic jejunal biopsy. Informed consent to carry out this procedure was obtained from the parents.
In 15 children a diagnosis of CMPI was made, based on a history of vomiting, diarrhoea, and weight loss (or exacerbation of eczema in atopic children) when on CM and improvement when on a $\mathrm{CM}$-free diet. Details of presenting symptoms, dietary history, and results of challenges are given in Table 1 . Four of these fifteen patients had additional allergies: to eggs (Nos. 6, 13, and 15), chicken, fish, and antibiotics (No. 11). Five of the fifteen had atopic symptoms such as eczema (Nos. 2, 8 and 13), asthma (No. 13), and urticaria (No. 6). Five patients (Nos. 4, 5, 9, 10 and 11) were challenged with $\mathrm{CM}$ at the time of investigation, and had pre- and postchallenge biopsies as previously described (34); patient No. 4 had a second challenge at age 18 months. In this group a total of 23 biopsies were performed, 16 while the patient was taking CM and 7 while the patient was on a CM-free diet.

Eight children whose symptoms could not be related to consumption of CM served as the control group. (Table 2). All were receiving $\mathrm{CM}$ at the time of jejunal biopsy.

Biopsy specimens. Upper jejunal biopsy specimens were obtained with a paediatric Crosby capsule. They were divided into at least two portions, which were fixed immediately, one for routine histology and one for immunofluorescence (15). Assessment of the villous morphology, normal or partial villous atrophy, was made as previously described (29).

Methods. $\beta$ LG (3 times crystallised) (Sigma London Chemical Co. Ltd., Poole, England) and BSA (Sigma, essentially globulinfree) were conjugated with FITC (Isomer I) (BDH Chemicals Ltd., Poole, England) and $\beta$ LG was also conjugated with TRITC (Isomer R, crystalline) (Nordic Immunological Laboratories, Maidenhead, England). The method used was derived from Johnson et al. (13) and Brandtzaeg (3). For FITC labelling, $1 \mathrm{mg}$ of dry FITC was added to a solution of $\beta \mathrm{LG}$ or BSA $(50 \mathrm{mg}$ in 4.5

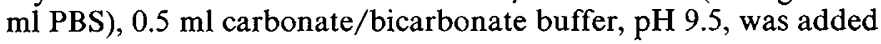
and the mixture rotated on a rotary mixer for $1 \mathrm{~h}$ at room temperature. The crude conjugate solution was dialysed for $24 \mathrm{~h}$ at $4^{\circ} \mathrm{C}$ against several changes of the starting buffer for ionexchange chromatography (see below), and then fractionated on a column of Whatman DE 52 (W. \& R. Balston Ltd., Maidstone, Kent, England) equilibrated with $0.01 \mathrm{M}$ phosphate buffer, $\mathrm{pH}$ 7.6. Elution was stepwise, with buffer containing increasingly larger concentrations of $\mathrm{NaCl}(0.1,0.15,0.2,0.3,0.4,0.6,0.8 \mathrm{M})$. The eluate was monitored at $280 \mathrm{~nm}$, fractions corresponding to the peaks pooled and the OD ratios (OD $280 \mathrm{~nm} / O D 495 \mathrm{~nm}$ ) measured.

Protein concentration was calculated using the equations given by Brandtzaeg (3), with the appropriate specific absorption as the divisor, and usually also determined by the Folin-Lowry method. The pooled fractions were concentrated by ultrafiltration through an Amicon PM 10 membrane (Amicon Ltd., Woking, Surrey, England) to a concentration of approximately $2 \mathrm{mg} / \mathrm{ml}$, divided into aliquots and stored at $-80^{\circ} \mathrm{C}$ with addition of $0.1 \mathrm{mg} / \mathrm{ml}$ sodium azide. For TRITC labelling of $\beta \mathrm{LG}, 1 \mathrm{mg}$ dry TRITC was added to $50 \mathrm{mg} \beta \mathrm{LG}$ as above, but the crude conjugate was filtered through a Sephadex G50 column, instead of dialysed, before ion-exchange chromatography. For OD ratio measurements peak absorption $(\lambda \max )$ for the sample of TRITC used 
Table 1. Clinical data on patients with cow's milk protein intolerance

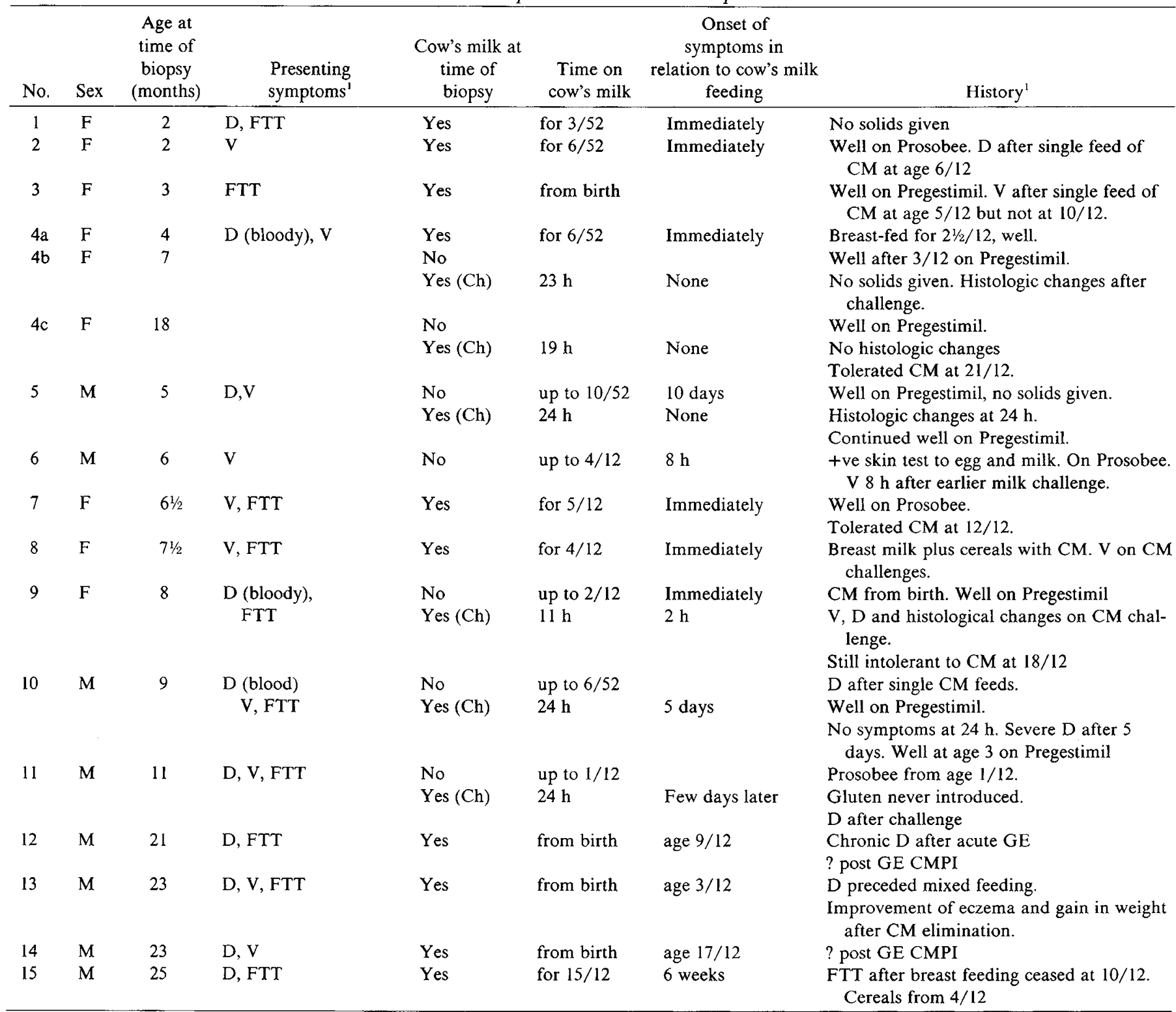

\footnotetext{
${ }^{1}$ Definitions: D, diarrhoea; V, vomiting; FTT, failure to thrive; CM, cow's milk; GE, gastroenteritis; CMPI, cow's milk protein intolerance; and Ch,
} challenge.

Table 2. Controls (on cow's milk) ${ }^{1}$

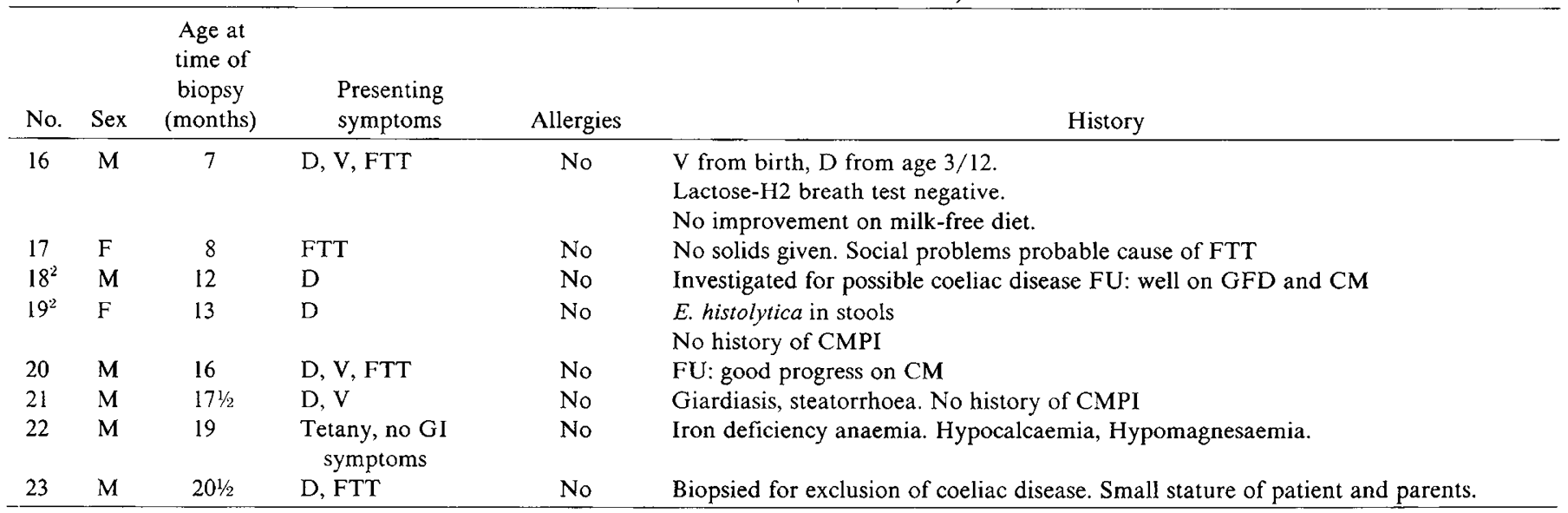

' Definitions: D, diarrhoea; V, vomiting; FTT, failure to thrive; FU, follow-up; CM, cow's milk; GFD, gluten-free diet; GE, gastroenteritis; and GI, gastrointestinal.

${ }^{2}$ Patients 18 and 19 were breast fed for $6 / 12$ and $2 / 12$ respectively. 
was $550 \mathrm{~nm}$. Fractions were assessed using a direct immunofluorescent staining technique on sections of lymph nodes from guinea pigs immunised with the appropriate antigen (see below). Fractions giving good staining of cells with absence of background were then used to investigate the clinical material.

The fractions of fluorochrome-labeled antigens that gave the best staining were as follows:

FITC- $\beta$ LG, fractions eluting with 0.3 and $0.4 \mathrm{M} \mathrm{NaCl}$, with OD ratios $1.3-1.4$, working concentration $0.2 \mathrm{mg} / \mathrm{ml}$.
FITC-BSA, fractions eluting with 0.2 and $0.4 \mathrm{M} \mathrm{NaCl}$, with OD ratios $1.2-1.35$, working concentration $0.2 \mathrm{mg} / \mathrm{ml}$. TRITC- $\beta$ LG, fractions eluting with 0.2 and $0.3 \mathrm{M} \mathrm{NaCl}$, with OD ratios $2.4-2.9$, working concentration $0.4 \mathrm{mg}$ / ml.

Other reagents used included TRITC-BSA (Nordic), rabbit FITC-conjugated anti-human IgA, IgG, IgM (Dako Immunoglobulins, Mercia Brocades Ltd., Weybridge, Surrey, England) and IgE (Behring, Hoechst Pharmaceuticals, Hounslow, England),

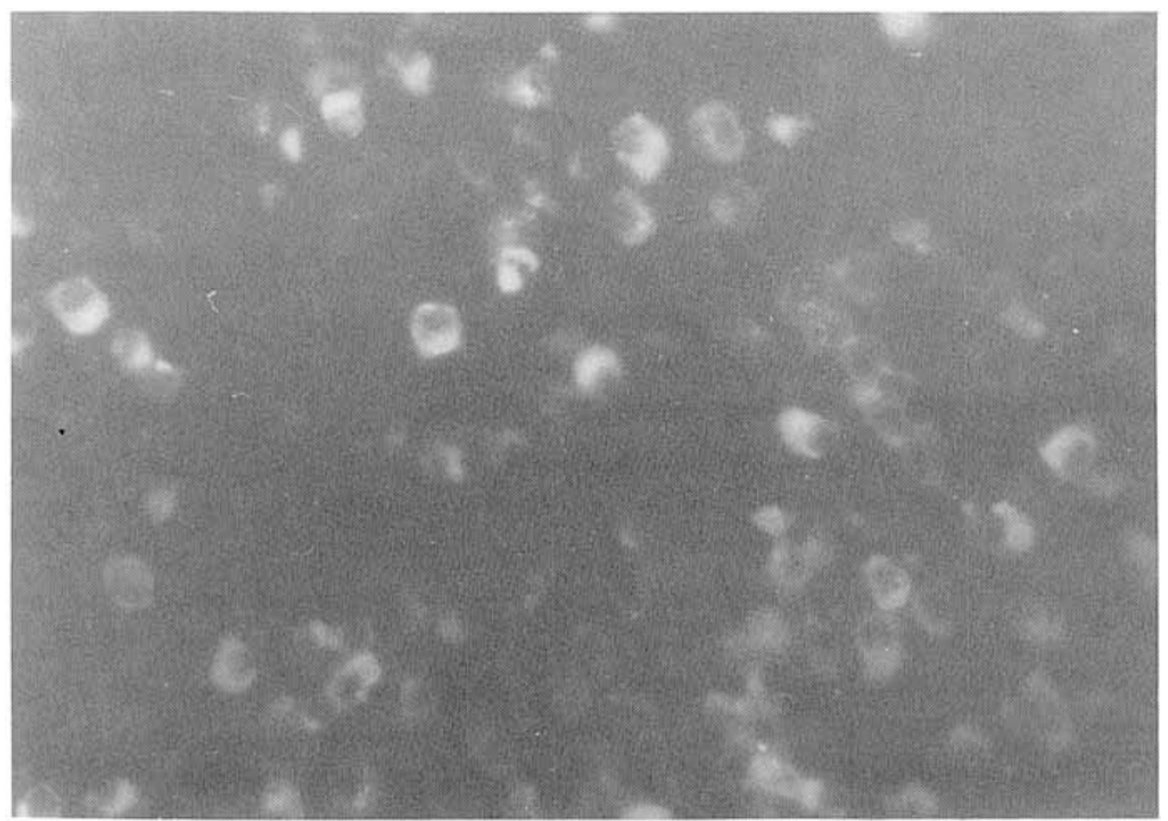

Fig. 1. Cervical lymph node from a guinea-pig immunised with $\beta$-lactoglobulin. Section incubated with fluorescein labeled- $\beta$-lactoglobulin. Numerous fluorescent plasma cells are present. $\times 625$.

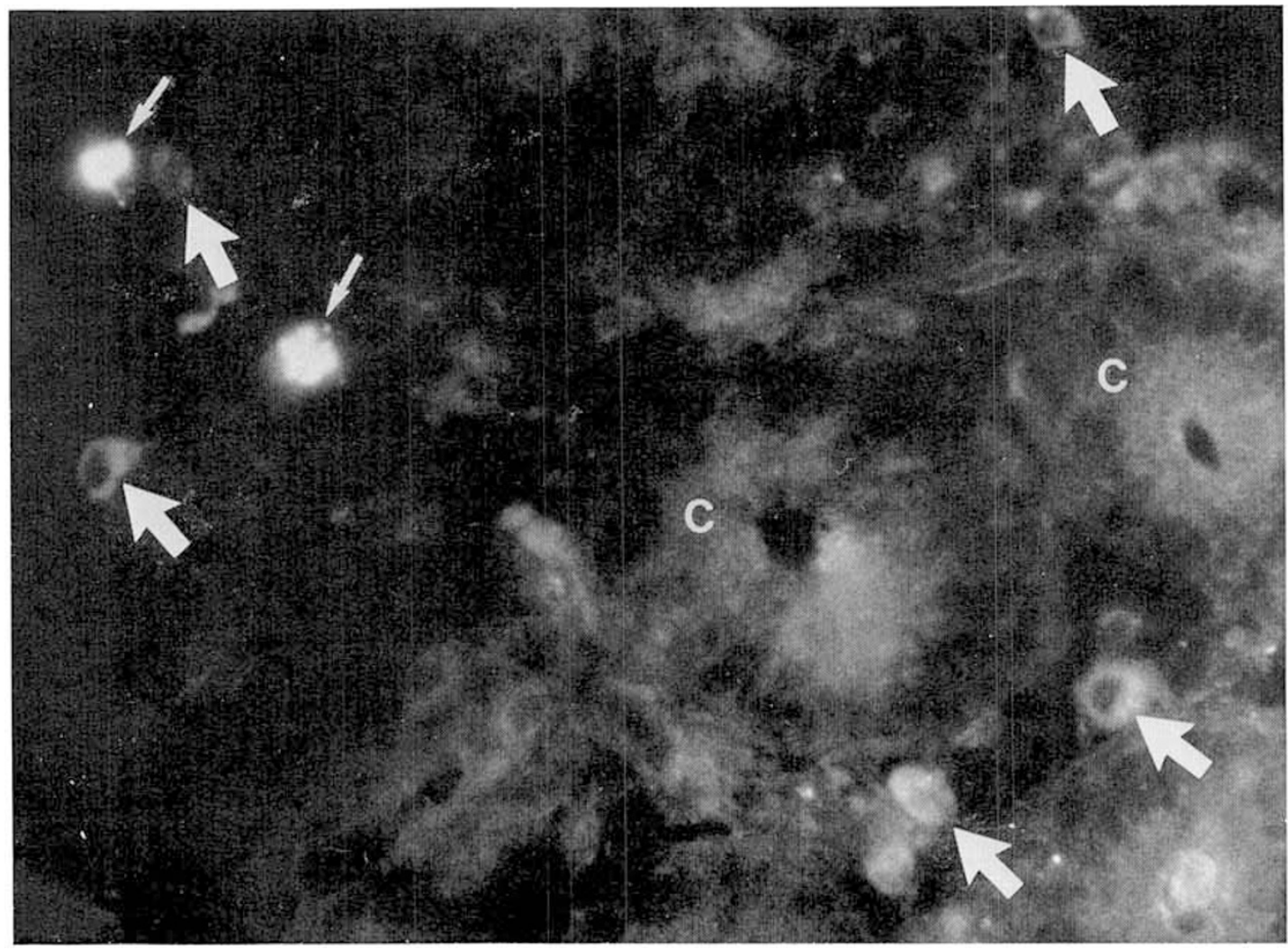

Fig. 2. Jejunal specimen from a child with cow's milk protein intolerance: cryostat section incubated with fluorescein labeled- $\beta$-lactoglobulin. Several green fluorescent plasma cells containing antibody to $\beta$-lactoglobulin are present (large arrows). Transmitted illumination also reveals orange-brown diaminobenzidine-stained eosinophils (small arrows). These would not be visible with incident illumination. C, crypt $\times 875$. 
3,3'-diaminobenzidine tetrahydrochloride (BDH Chemicals Ltd., Poole, England) and 30\% hydrogen peroxide $\left(\mathrm{H}_{2} \mathrm{O}_{2}\right)(\mathrm{BDH}$ Chemicals Ltd.). The anti-IgE was absorbed with $\kappa$ and $\lambda$ light chains before use to eliminate nonspecific immunoglobulin staining (15, 16).

Adult white guinea pigs were sensitised by multiple intradermal injections in the suprascapular region of $1 \mathrm{mg}$ of $\beta \mathrm{LG}$ or BSA in $0.5 \mathrm{ml}$ of Freund's incomplete adjuvant. After $3 \mathrm{wk}$ the animals were killed and the draining lymph nodes removed and processed for immunofluorescence (17).

Immunofluorescent staining of plasma cells for immunoglobulin (Ig) class was carried out as previously described (17). Staining for specific antibody with conjugated $\beta \mathrm{LG}$ and BSA was carried out similarly, but after a 15-min wash in PBS, sections were treated with $\mathrm{DAB}$ and $\mathrm{H}_{2} \mathrm{O}_{2}$ to mask nonspecific fluorescent staining of eosinophils (15) [see also (39)]. Controls were included of similar sections pretreated with unlabeled antigen and sections from control animals where appropriate. In double immunofluorescent staining of biopsies the sections were first incubated with TRITC-labeled $\beta$ LG or BSA, followed by FITC-anti-human Ig's (class specific) with no intervening PBS wash.

Sections were examined with a Leitz Orthoplan microscope (E. Leitz Instruments Ltd., Luton, England) equipped with a Ploemtype vertical illuminator and a Wotan HBO $200 \mathrm{~W}$ lamp. Photography was with an Orthomat microscope camera (Leitz) using Kodak Ektachrome 400 film. This caused troublesome fading of fluorescence until our attention was drawn to the fact that addition of $1 \mathrm{mg} / \mathrm{ml}$ of $p$-phenylenediamine to the buffered glycerol mounting medium greatly retarded immunofluorescent fading (14).

\section{RESULTS}

Antigen binding cells could be demonstrated in sections of guinea pig lymph nodes using the appropriate fluorochromelabeled antigen. These cells were round or oval with a large round eccentric nucleus and strongly fluorescent agranular cytoplasm and were considered to be plasma cells containing specific antibody. Nodes from animals sensitised to $\beta \mathrm{LG}$ contained $\beta \mathrm{LG}-$ binding cells (Fig. 1.), which were not seen in sections pretreated with unlabeled $\beta$ LG. Similarly, nodes from animals sensitised to BSA contained BSA-binding cells, which were not seen in sections pretreated with unlabeled BSA. BSA-sensitised nodes contained no $\beta \mathrm{LG}$-binding cells and $\beta \mathrm{LG}$-sensitised nodes contained no BSA-binding cells.

Cells binding $\beta \mathrm{LG}$ and BSA were also identified in many of

Table 3. Antibody-containing cells (ACC) to $\beta$-lactoglobulin and bovine serum albumin in the jejunal mucosa of cow's milk protein intolerance children taking cow's milk ${ }^{1}$

\begin{tabular}{ccccc}
\hline Patient No. & $\begin{array}{c}\beta \text {-LG } \\
\text { ACC }\end{array}$ & $\begin{array}{c}\text { BSA } \\
\text { ACC }\end{array}$ & Histology & $\begin{array}{c}\text { IgA plasma } \\
\text { cells }^{2}\end{array}$ \\
\hline 1 & + & $\ldots$ & PVA & 55 \\
2 & + & - & PVA & 32 \\
3 & + & - & PVA & 19 \\
$4 \mathrm{a}$ & + & $\ldots$ & PVA & 91 \\
$4 \mathrm{~b}$ & + & $\ldots$ & PVA & $\ldots$ \\
$4 \mathrm{c}$ & + & $\ldots$ & N & 77 \\
5 & - & $\ldots$ & PVA & 72 \\
7 & - & - & PVA & $\ldots$ \\
8 & - & - & N & 22 \\
9 & + & $\ldots$ & PVA & $\ldots$ \\
10 & - & $\ldots$ & PVA & $\ldots$ \\
11 & + & - & N & 77 \\
12 & + & + & PVA & 38 \\
13 & + & + & PVA & 65 \\
14 & - & $\ldots$ & PVA & 30 \\
15 & + & - & N & 72 \\
\hline
\end{tabular}

\footnotetext{
'Definitions: +, present; -, absent; ..., not done; N, normal histology; PVA, partial villous atrophy; $\beta \mathrm{LG}, \beta$-lactoglobulin; and BSA, bovine serum albumin.

${ }^{2}$ No. per $232 \mu \mathrm{m}$ mucosal unit (21).
}

Table 4. ACC to $\beta-L G$ in the jejunal mucosa of cow's milk protein intolerance children on a cow's milk-free diet ${ }^{1,2}$

\begin{tabular}{cccc}
\hline Patient No. & $\begin{array}{c}\beta \text {-LG } \\
\text { ACC }\end{array}$ & Histology & $\begin{array}{c}\text { IgA plasma } \\
\text { cells }^{3}\end{array}$ \\
\hline $4 \mathrm{~b}$ & $\ldots$ & PVA & 96 \\
$4 \mathrm{c}$ & - & N & 60 \\
5 & - & N & 56 \\
6 & - & PVA & 49 \\
9 & + & N & $\ldots$ \\
10 & - & PVA & 52 \\
11 & - & N & 58 \\
\hline
\end{tabular}

${ }^{1}$ BSA-ACC not done in this group.

${ }^{2}$ Definitions: + , present; - , absent; ..., not done; $N$, normal; PVA, partial villous atrophy; $\mathrm{ACC}$, antibody-containing cell; $\beta \mathrm{LG}, \beta$-lactoglobulin; and BSA, bovine serum albumin.

${ }^{3}$ No. per $232 \mu \mathrm{m}$ mucosal unit (2l).

Table 5. ACC to $\beta-L G$ and bovine serum albumin in the jejunal mucosa of control children taking cow's milk ${ }^{1}$

\begin{tabular}{|c|c|c|c|c|}
\hline Patient No. & $\begin{array}{l}\beta-\mathrm{LG} \\
\mathrm{ACC}\end{array}$ & $\begin{array}{l}\text { BSA } \\
\text { ACC }\end{array}$ & Histology & $\begin{array}{l}\text { IgA plasma } \\
\text { cells }^{2}\end{array}$ \\
\hline 16 & - & $\ldots$ & PVA & 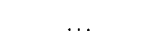 \\
\hline 17 & - & - & $\mathrm{N}$ & 80 \\
\hline 18 & - & - & PVA & 63 \\
\hline 19 & - & - & $\mathrm{N}$ & 23 \\
\hline 20 & - & - & PVA & 38 \\
\hline 21 & - & - & PVA & 28 \\
\hline 22 & + & + & $\mathrm{N}$ & 42 \\
\hline 23 & - & - & $\mathrm{N}$ & $\ldots$ \\
\hline
\end{tabular}

${ }^{1}$ Definitions: + , present; - , absent; ..., not done; $N$, normal; PVA, partial villous atrophy; ACC, antibody-containing cells; $\beta$-LG, $\beta$-lactoglobulin; and BSA, bovine serum albumin.

${ }^{2}$ No. per $232 \mu \mathrm{m}$ mucosal unit (21).

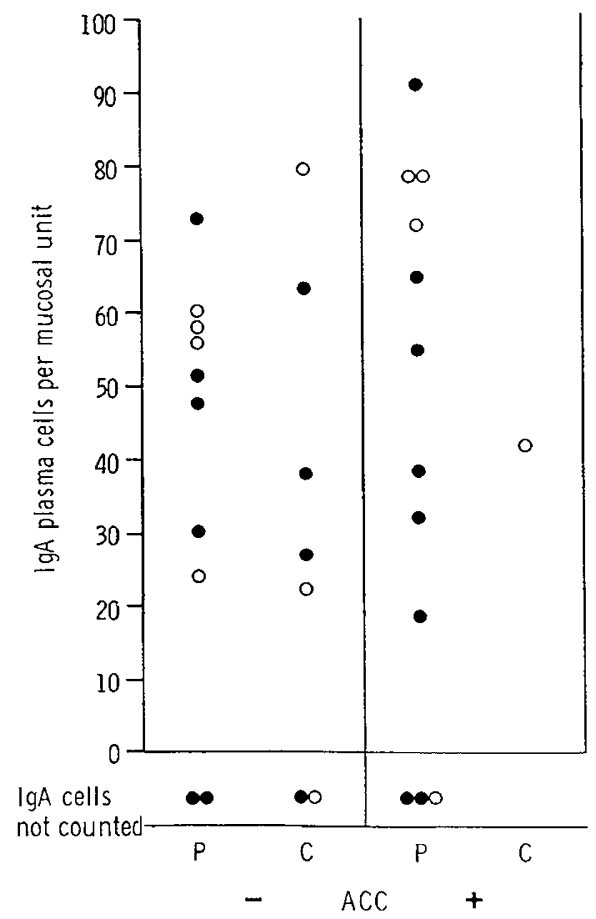

Fig. 3. Scatter diagram showing IgA plasma cell counts and histology of jejunal mucosa with $(+)$ and without $(-)$ antibody-containing cells. $\boldsymbol{\bullet}$, partial villous atrophy; $\mathrm{O}$, normal histology; $\mathrm{P}$, patients; and $\mathrm{C}$, controls.

the jejunal mucosal specimens (Fig. 2). Specificity of the reaction was established by blocking with unlabeled antigen as in the guinea-pig lymph nodes. The response to antigen was considered to be positive if two or more ACC could be identified in two or 
more sections. In all but three of the positive specimens the number of ACC was greater than this minimum. They varied from about $0.5 \%$ to (in one specimen-patient 12 ) $5 \%$ of the total $(\operatorname{Ig} \mathrm{A}+\operatorname{IgM})$ plasma cells.

The 16 biopsies from CMPI children taking CM were all tested with $\beta \mathrm{LG}$, and eight were also tested with BSA. Eleven of the 16 were positive for $\beta \mathrm{LG}$, and two of these 11 were also positive for BSA (Table 3). Only one of the six biopsies from children who were on a milk-free diet was positive for $\beta \mathrm{LG}$ (Table 4). In the control group (Table 5) all except one (No. 16) were tested with both antigens and all but one (No. 22) were negative.

The majority (12 out of 16) of the biopsies from patients with CMPI on CM showed partial villous atrophy, and this also occurred in two of the seven biopsies from patients on a CM-free diet and four of the eight controls. [Previous work (29) has shown that partial villous atrophy occurs frequently in children, even those with no gastrointestinal symptoms.] But the presence of ACC did not correlate with histologic abnormality either in the patient group or in the control group, and neither did it correlate with the IgA plasma cell count (Fig. 3).

Double immunofluorescent staining was performed on three biopsies (patient Nos. 11,13, and 15). The majority of ACC were found to be of IgA class (Fig. 4) but IgE ACC were also observed in patients 13 and 15 (Fig. 5). No IgM or IgG ACC could be detected. Counts, necessarily performed on separate sections, gave estimates of 64 and $83 \%$ of the ACC as IgA class and 40 and $17 \%$ as IgE class.

\section{DISCUSSION}

In this study we have described a simple method that can be used on fresh and stored biopsy material to measure local mucosal antibody response to defined dietary proteins. This technique does not require any special equipment and falls well within the capabilities of a routine pathology laboratory. Brandtzaeg and Baklien (4) used a "sandwich" version of this method to demonstrate cells producing antibodies to a gliadin digest in the intestinal mucosa of a patient with coeliac disease and similar methods have been used for animal studies $(6,31)$. The direct method we have used may be less sensitive, but avoids having to raise specific antisera.

We have found that cells containing antibodies to antigens contained in cow's milk are present in the human jejunal mucosa, and they occur far more frequently in children with CMPI, when
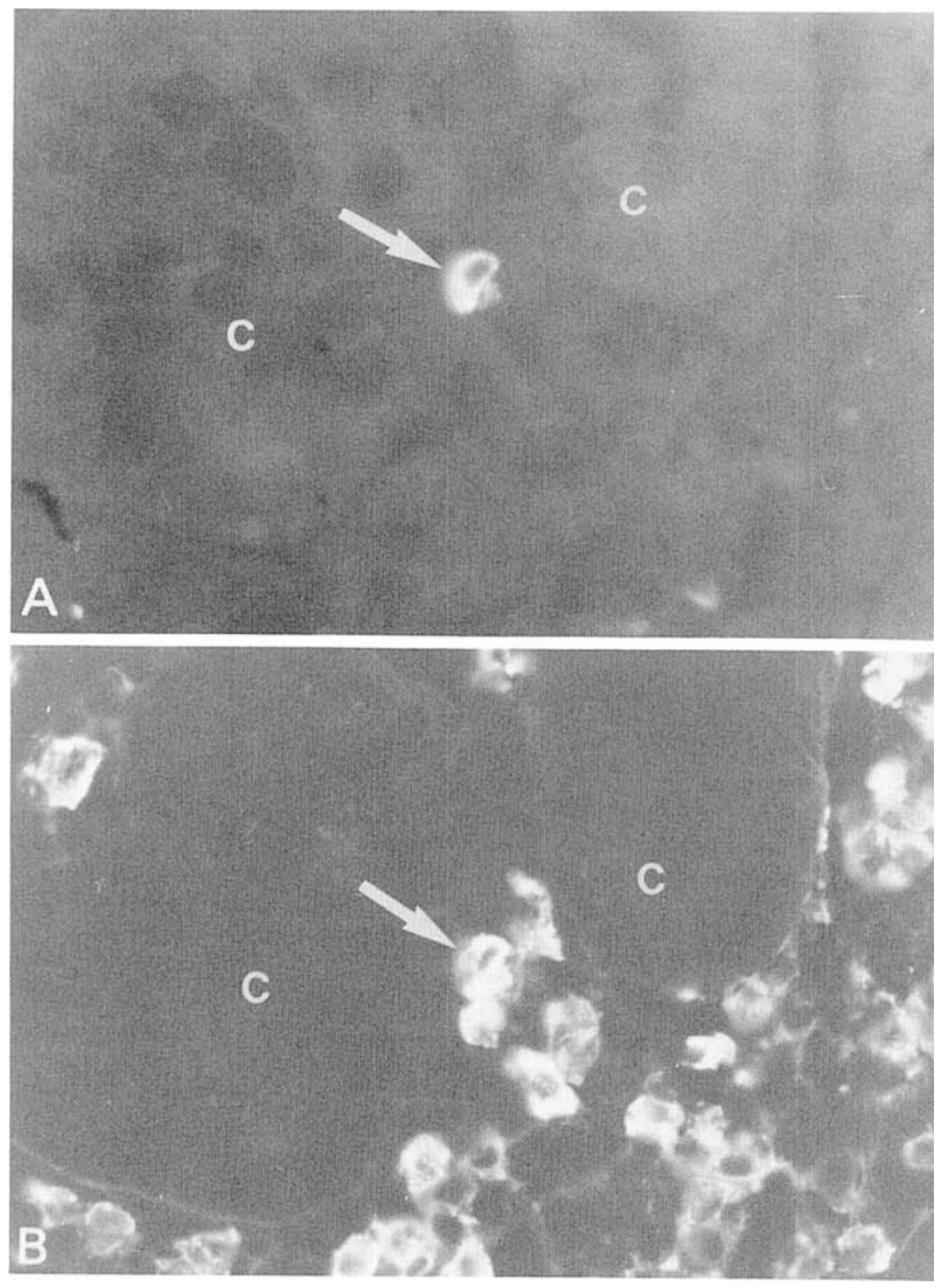

Fig. 4. Double immunofluorescent staining in jejunal mucosa. Cryostat section treated with rhodamine-labeled $\beta$-lactoglobulin and fluorescein labeled-anti-IgA. Same microscopic field photographed through appropriate filters to show $(A)$ cell binding $\beta$-lactoglobulin, $(B) \operatorname{Ig} A$ plasma cells: arrowed cells are identical. C, crypt $\times 625$. 

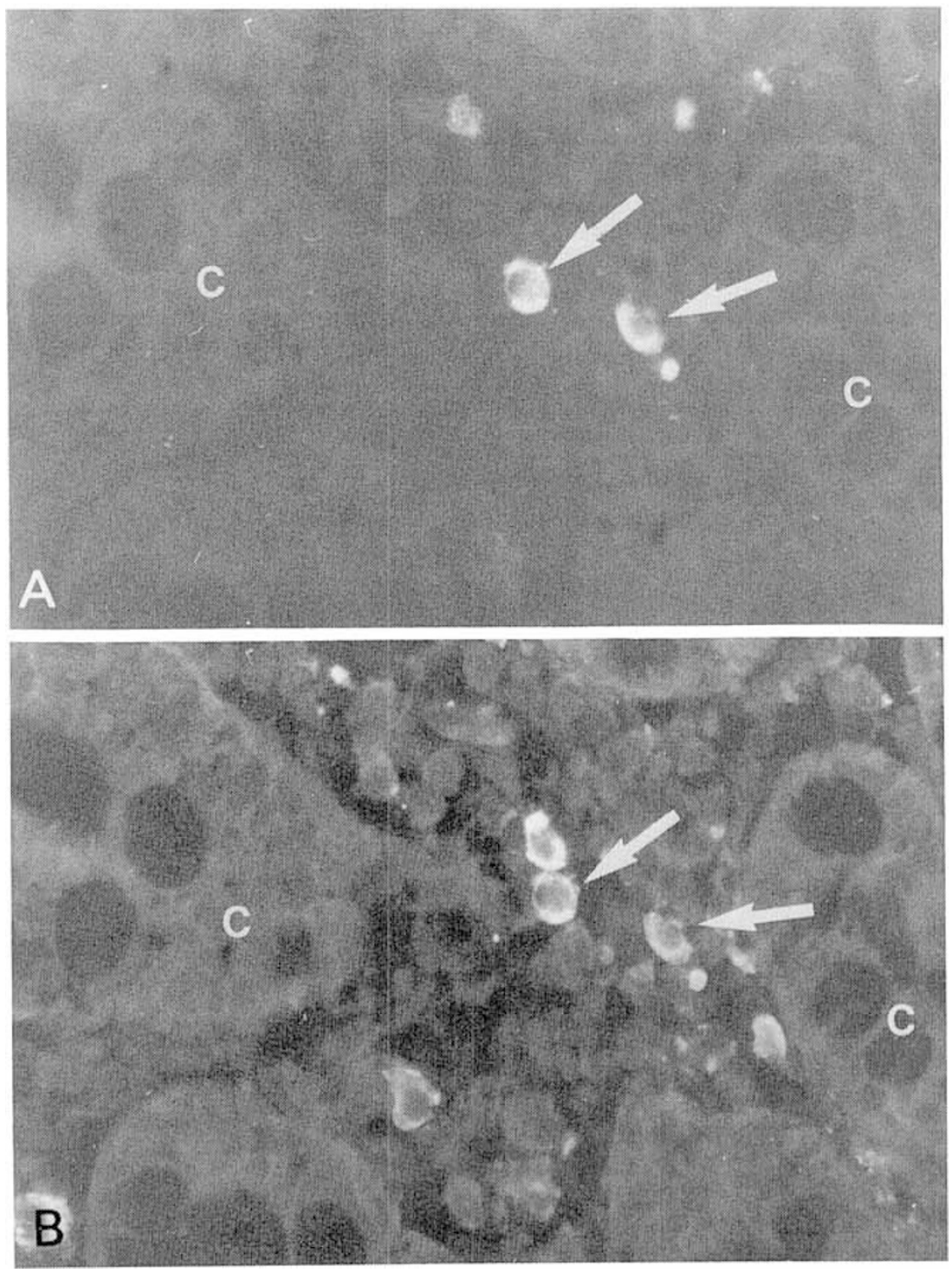

Fig. 5. Double immunofluorescent staining with rhodamine-labeled bovine serum albumin and fluorescein labeled-anti-IgE in jejunal mucosa: $(A)$ cells binding bovine serum albumin $(B) \operatorname{IgE}($ ? plasma) cells: arrowed cells are identical. C, crypt $\times 625$.

on CM, than in a control group also on CM or in CMPI children on a CM-free diet.

The presence in jejunal biopsies of ACC demonstrated in this way may be diagnostically useful in allergic enteropathies; however, it may be that the presence of ACC merely reflects a mucosa that is unusually leaky to antigen together with the presence of milk proteins in the diet. This did not seem to be the case in our study, as the occurrence of ACC did not correlate with histologic abnormality (Fig. 3), which has been considered to be associated with increased permeability to antigen (21). Such a situation might, however, exist in coeliac disease (19). Further, as it is possible that several different mechanisms may be responsible for CMPI (8) with varying components of local and systemic responses, the numbers of local ACC may be different in different groups of CMPI patients. There are also uncertainties in the kinetics of the plasma cell response. Pierce and Gowans (31), investigating the immune response to cholera toxoid in rats, found that in primed animals ACC started to appear about 3 days after challenge, reached their maximum number at about 5 days, and had disappeared by about 10 days. [A similar life expectancy for IgA plasma cells in the gut has been found in other animal studies (25)]. Although ACC are likely to disappear fairly rapidly on an antigen-free diet, it is possible that a longer time interval than is normally assumed may be necessary for their appearance after antigen challenge. This would account for the absence of ACC in some of our postchallenge biopsies taken $24 \mathrm{~h}$ or less after challenge [There is, however, evidence for long-lived IgE secreting cells $(24,28)]$.

It is necessary to be cautious about the implications of our observations for the pathogenesis of CMPI. Circulating antibodies to dietary proteins have been fairly extensively studied $(1,18)$ but circulating antibodies do not necessarily reflect accurately what is going on locally in the mucosa $(2,32)$. Whereas $\operatorname{IgA}$ almost certainly has a role in antigen exclusion $(36,38)$ and antigen elimination via the hepato-biliary system $(30,42) \operatorname{IgE}$ antibodies are likely to be damaging. It is certain that IgE plasma cells do occur in the human intestinal mucosa $(26)$ in contrast to the suggestion from animal studies that the $\mathrm{IgE}$ containing cells were mast cells (22). We have seen cells with separate affinities for BSA and $\beta \mathrm{LG}$ in a section from a biopsy containing IgE-ACC, but none with mixed specificity, such as would be expected to occur in mast cells. This suggests that some at least of our IgE-ACC were in fact plasma cells rather than mast cells; thus, we have evidence suggestive of a local production of reaginic antibodies to food proteins, which could mediate gastrointestinal allergy or open the mucosal 'gate' to allow increased antigen entry $(5,35)$.

We conclude that this simple technique adds useful antigenspecific immunologic data to the information that can be obtained 
from intestinal biopsies. It is likely to be helpful in elucidating the mechanisms of food allergy, but requires further study before it can be used diagnostically in CMPI.

\section{REFERENCES AND NOTES}

1. Ahlstedt, S., Carlsson, B., Fällström, S. P., Hanson, L. Å., Holmgren, J., LiddinJanson, G., Lindblad, B. S., Jodal, U., Kaijser, B., Sohl-Åkerlund, B., SohlÅkerlund, A., and Wadsworth, C.: Antibodies in human serum and milk induced by enterobacteria and food proteins. In: Immunology of the gut. Ciba Foundation Symposium 46 (new series) pp 115-134 (Elsevier, Amsterdam, 1977).

2. André, C., André, F., Druguet, M., and Fargier, M-C.: Response of anamnaestic IgA-producing cells in the mouse gut after repeated intragastric immunisation. Adv. Exp. Med. Biol., 107: 583 (1978).

3. Brandtzaeg, $P$.: Conjugates of immunoglobulin $G$ with different fluorochromes. I. Characterization by anionic-exchange chromatography. Scand. J. Immunol., 2:273 (1973).

4. Brandtzaeg, P. and Baklien, K.: Immunohistochemical studies of the formation and epithelial transport of immunoglobulins in normal and diseased human intestinal mucosa. Scand. J. Gastroenterol., II Suppl 36: I (1976).

5. Brostoff, J., Carini, C., Wraith, D. G., and Johns, P.: Production of IgE complexes by allergen challenge in atopic patients and the effect of sodium cromoglycate. Lancet, I: 1268 (1979).

6. Crabbé, P. A., Nash, D. R., Bazin, H.. Eyssen, H., and Heremans, J. F. Antibodies of the IgA type in intestinal plasma cells of germ-free mice after oral or parenteral immunization with ferritin. J. Exp. Med., 130: 723 (1969).

7. Dannaeus, A. and Johansson, S. G. O.: A follow-up study of infants with adverse reactions to cow's milk. 1. Serum IgE, skin test reactions and RAST in relation to clinical course. Acta Paediatr. Scand., 68: 377 (1979).

8. Ferguson, A.: Celiac disease and gastrointestinal food allergy. In: A. Ferguson, R. N. M. MacSween: Immunological aspects of the liver and gastrointestinal tract pp 154-202 (MTP Press Ltd, Lancaster, 1976.)

9. Fontaine, J. L. and Navarro, J.: Small intestinal biopsy in cow's milk protein allergy in infancy. Arch. Dis. Child., 50: 357 (1975).

10. Harrison, M., Kilby, A., Walker-Smith, J. A., France, N. E., and Wood, C. B. S. Cow's milk protein intolerance: a possible association with gastroenteritis, lactose intolerance and IgA deficiency. Brit. Med. J., 1: 1501 (1976).

11. Hill, D. J., Davidson, G. P., Cameron, D. J. S., and Barnes, G. L.: The spectrum of cow's milk allergy in childhood. Clinical, gastroenterological and immunological studies. Acta Paediatr. Scand., 68: 847 (1979).

12. Iyngkaran. N., Robinson, M. J., Prathap, K., Sumithran, E., and Yadav, M.: Cow's milk protein-sensitive enteropathy. Combined Clinical and histological criteria for diagnosis. Arch. Dis. Child., 53: 20 (1978).

13. Johnson, G. D.. Holborow, E. J., and Dorling, J.: Immunofluorescence and immunoenzyme techniques. In: D. M. Weir: Handbook of experimental immunology. 3rd Ed. p. 15.1 (Oxford. Blackwell 1978).

14. Johnson, G. D. and Nogueira Aranjo, G. M. de C.: A simple method of reducing the fading of immunofluorescence during microscopy. J. Immunol. Methods, 43: 349 (1981).

15. Kingston, D. and Pearson, J. R.: The use of the peroxidase reaction to obliterate staining of eosinophils by fluorescein-labelled conjugates. J. Immunol. Methods, 44: 191 (1981).

16. Kingston. D., Pearson. J., and Shiner, M.: The mast cell in gastrointestinal allergy. In: J. Pepys, A. M. Edwards: The Mast Cell pp. 394-405 (Pitman, London, 1979).

17. Kingston, D., Pearson, J. R., and Penna, F. J.: Plasma cell counts of human jejunal biopsy specimens examined by immunofluorescence and immunoperoxidase techniques: a comparative study. J. Clin. Pathol., 34: 381 (1981).

18. Kletter, B., Gery, I., Freier, S., and Davies, A. M.: Immune responses of normal infants to cow milk. I. Antibody type and kinetics of production. Int. Arch. Allergy, 40: 656 (1971).

19. Kumar, P. J., Ferguson. A., Lancaster-Smith, M., and Clark, M. L.: Food antibodies in patients with dermatitis herpetiformis and adult coeliac diseaserelationship to jejunal morphology. Scand. J. Gastroenterol., 11: 5 (1976).
20. Lessof, M. H., Wraith, D. G., Merrett, T. G., Merrett, J., and Buisseret, P. D. Food allergy and intolerance in 100 patients-Local and systemic effects. Quart. J. Med., 49: 259 (1980).

21. Maffei, H. V. L., Kingston, D., Hill, I. D., and Shiner, M.: Histopathologic changes and the immune response within the jejunal mucosa in infants and children. Pediatr. Res., 13: 733 (1979)

22. Mayrhofer, G., Bazin, H. and Gowans, J. L.: Nature of cells binding anti-IgE in rats immunised with Nippostrongylus brasiliensis. IgE synthesis in regional nodes and concentration in mucosal mast cells. Eur. J. Immunol., 6: 537 (1976).

23. Moticka, E. J.: The non-specific stimulation of immunoglobulin secretion following specific stimulation of the immune system. Immunology, 27: 401 (1974).

24. Okudaira, H. and Ishizaka, K.: Reaginic antibody formation in the mouse. XI Participation of long-lived antibody-forming cells in persistent antibody formation. Cell. Immunol., 58: 188 (1981).

25. Ottaway, C. A., Rose, M. L. and Parrott, D. M. F.: The gut as an immunological system. Int. Rev. Physiol., 19: 323 (1979).

26. Patterson, S., Roebuck, P., Platts-Mills, T. A. E., Shiner, M., Kingston, D., and Pearson, J. R.: IgE plasma cells in human jejunum demonstrated by immune electron microscopy. Clin. Exp. Immunol., 46: 301 (1981).

27. Pearson, J. R., Kingston, D., and Shiner, M.: Antibody production to milk proteins in the jejunal mucosa of children with cow's milk protein intolerance (CMPI). Pediatr. Res. (Abstract), 15: 1200 (1981).

28. Peeters, S. H. and Carter, B. G.: Regulation of the IgE antibody response in mice II. Radioresistance of established IgE antibody production. Immunology, 43 25 (1981).

29. Penna, F. J., Hill, I. D., Kingston, D., Robertson, K., Slavin, G., and Shiner, M. Jejunal mucosal morphometry in children with and without gut symptoms and in normal adults. J. Clin. Pathol., 34: 386 (I981).

30. Peppard, J. V., Orians, E., Andrew, E., and Payne, A. W. R.: Elimination into bile of circulating antigen by endogenous IgA antibody in rats. Immunology, 45: 467 (1982)

31. Pierce, N. F. and Gowans, J. L.: Cellular kinetics of the intestinal immune response to cholera toxoid in rats. J. Exp. Med., 142: 1550 (1975).

32. Platts-Mills, T. A. E.: Local production of $\operatorname{IgG}$, IgA and $\operatorname{IgE}$ antibodies in grass pollen hay fever. J. Immunol., 122: 2218 (1979).

33. Savilahti, E.: Immunochemical study of the malabsorption syndrome with cow's milk intolerance. Gut, 14: 49l (1973)

34. Shiner, M., Ballard, J. and Smith, M. E.: The small-intestinal mucosa in cow's milk allergy. Lancet, $1: 136$ (1975).

35. Steinberg, P., Ishizaka, K. and Norman, P. S.: Possible role of IgE-mediated reaction in immunity. J. Allergy Clin. Immunol., 54: 359 (1974).

36. Swarbrick, E. T., Stokes, C. R., and Soothill, J. F.: Absorption of antigens after oral immunisation and the simultaneous induction of specific systemic tolerance. Gut, 20: 121 (1979)

37. Ternynck, T., Robrigot, M., and Avrameas, S.: Kinetics of antibody and immunoglobulin-producing cells appearing in popliteal lymph nodes of mice stimulated with horseradish peroxidase. J. Immunol., 119: 1321 (1977).

38. Tolo, K., Brandtzaeg, P., and Jonsen, J.: Mucosal penetration of antigen in the presence or absence of serum-derived antibody. Immunology, 33: 733 (1977).

39. Valnes, K. and Brandtzaeg, P.: Selective inhibition of non-specific eosinophil staining or identification of eosinophilic granulocytes by paired counterstaining in immunofluorescence studies. J. Histochem. Cytochem., 29: 595 (1981).

40. Walker-Smith, J., Harrison, M., Kilby, A.., Phillips, A., and France, N.: Cow's milk-sensitive enteropathy. Arch. Dis. Child., 53: 375 (1978).

41. Withrington, R. and Challacombe, D. N.: Eosinophil counts in duodenal tissue in cow's milk allergy. Lancet, 1: 675 (1979).

42. Delacroix, D. L., Hodgson, H. J. F., McPherson, M., Dive, C. and Vaerman, J P.: Selective transport of polymeric immunoglobulin $\mathrm{A}$ in bile. Quantitative relationships of monomeric and polymeric immunoglobulin A, immunoglobulin $\mathrm{M}$ and other proteins in serum, bile and saliva. J. Clin. Invest. 70:230 (1982).

43. Requests for reprints should be addressed to: Joy R. Pearson. Clinical Research Centre, Watford Road, Harrow HAI 3UJ, England.

44. Received for publication March 22, 1982.

45. Accepted for publication September 10,1982. 